\title{
Lysis Induced by Sodium Ion and Its Relation to Lytic Enzyme Systems in Clostridium saccharoperbutylacetonicum
}

\author{
By S. OGATA AND M. HONGO \\ Laboratory of Applied Microbiology, Department of Agricultural Chemistry, \\ Kyushu University, Fukuoka, Japan
}

(Received I I May 1973; revised I3 August 1973)

SUMMARY

Growing Clostridium saccharoperbutylacetonicum was lysed by sodium ion concentrations above $0.1 \mathrm{M}$ (maximum effect at $0.3 \mathrm{M}$ ). The rate of lysis depended on the age of the culture. The most rapid lysis occurred in organisms from logarithmically growing cultures which were incubated for 3 to $5 \mathrm{~h}$; organisms from stationary phase cultures were completely resistant to $\mathrm{Na}^{+}$-induced lysis. Sodium ioninduced lysis was related to autolysis of the organisms and was greatly affected by $\mathrm{pH}$ and temperature. The optimum $\mathrm{pH}$ was about $6 \cdot 0$, and the optimum temperature $35^{\circ} \mathrm{C}$. Various chemical inhibitors, including known enzyme inhibitors (such as $\mathrm{Cu}^{2+}$ and $p$-chloromercuribenzoate) and fixative agents (such as formalin and glutaraldehyde), inhibited the lysis, while organisms whose growth had been inhibited by antibiotics such as tetracycline, were also resistant to $\mathrm{Na}^{+}$-induced lysis. The lysate produced by $\mathrm{Na}^{+}$-treatment itself had lytic activity on isolated walls, thought to be due to its content of autolysin.

About 30 to 60 min after mitomycin $\mathrm{C}$ treatment (which induced the production of the phage tail-like bacteriocin clostocin $\mathrm{O}$ ), the organisms were temporarily resistant to $\mathrm{Na}^{+}$-induced lysis. However the organisms reverted to the state of high sensitivity to $\mathrm{Na}^{+}$when clostocin $\mathrm{O}$-associated endolysin was produced. We suggest that $\mathrm{Na}^{+}$-induced lysis is due to the action of wall lytic enzymes such as autolysin and clostocin O-endolysin.

\section{INTRODUCTION}

In a previous paper (Ogata \& Hongo, 1973), we showed that growing organisms of Clostridium species were lysed by univalent cations such as $\mathrm{Na}^{+}, \mathrm{K}^{+}, \mathrm{Rb}^{+}, \mathrm{Cs}^{+}, \mathrm{Li}^{+}$, and $\mathrm{NH}_{4}{ }^{+}$. Of various pathogenic and non-pathogenic Clostridium species, strains of C. saccharoperbutylacetonicum were the most sensitive to univalent cations. The lytic action of $\mathrm{Na}^{+}$ was displayed at concentrations greater than $O^{\cdot I} \mathbf{M}$, this ion having maximum effect at $0.3 \mathrm{M}$. Bivalent cations such as $\mathrm{Ca}^{2+}, \mathrm{Mg}^{2+}, \mathrm{Ba}^{2+}, \mathrm{Co}^{2+}$ and $\mathrm{Ni}^{2+}$ at above $0.005 \mathrm{M}$ inhibited this lysis, whereas chelating agents such as EDTA and sodium citrate at concentrations above 0 .0I $M$ enhanced it. Therefore, the lysis seemed to depend on antagonism between added univalent cations and bivalent cations present in the medium and on the bacterial surface. However, from our findings it appeared that the lysis might not only be due to such ion antagonism, but to action of some lytic enzymes such as autolysin.

Very similar observations have been made in studies of the sensitivity of Bacillus subtilis to saline: when harvested at the logarithmic phase of growth they lost their colony-forming ability in $0.15 \mathrm{M}-\mathrm{NaCl}$ (Iizima \& Ikeda, I969). The saline-sensitive organisms were generally competent (i.e. able to take up DNA and produce transformants). It is well known (Young \& Spizizen, 1963; Young, r966; Stewart \& Marmur, 1970) that there is a remarkable 
correlation between an organism's autolytic propensity and its ability to undergo transformation. Saline sensitivity was also displayed by Escherichia coli (Sato, Suzuki, Izaki \& Takahashi, I97I ; Sato, Izaki \& Takahashi, 1972), so that our findings should be compared with reports of other instances of saline sensitivity.

\section{METHODS}

Organism. The strain used was NI-4 (ATCC13564) of Clostridium saccharoperbutylacetonicum (Hongo \& Murata, I965) previously found to be particularly sensitive to $\mathrm{Na}^{+}$induced lysis.

Medium and cultural conditions. Growth was at $30{ }^{\circ} \mathrm{C}$ under lowered atmospheric pressure ( 5 to $10 \mathrm{~mm} \mathrm{Hg}$ ) in TYA broth (Hongo \& Murata, 1965) which contained (g/l distilled water): glucose, 40; Bacto-tryptone (Difco), 6; yeast extract (Daigo Eiyo Kagaku Co.) 2; ammonium acetate, $3 ; \mathrm{KH}_{2} \mathrm{PO}_{4}, 0.5 ; \mathrm{MgSO}_{4} .7 \mathrm{H}_{2} \mathrm{O}, 0.4$ (approx. $0.00 \mathrm{I} \mathrm{M}-\mathrm{Mg}^{2+}$ ); $\mathrm{FeSO}_{4}$. $7 \mathrm{H}_{2} \mathrm{O}, 0.0 \mathrm{I}$; at $\mathrm{pH} 6.5$. To obtain a young exponentially growing culture, fresh medium was inoculated with sufficient organisms to produce an initial extinction $(E)$ of 0.1 at $660 \mathrm{~nm}$, and unless otherwise mentioned the culture was incubated until its $E_{660}$ became 0.30 (I0 organisms $/ \mathrm{ml}$ ).

Turbidity measurements. Extinction $(E)$ of the culture or bacterial suspension was measured at $660 \mathrm{~nm}$ with a photoelectric colorimeter (model $7 \mathrm{~A}$, Tokyo Koden Co. or type-Ior, Hitachi Co.), as previously described (Ogata, Mihara, Ikeda \& Hongo, I972).

Induction of bacterial lysis by sodium ions. In general, the organisms were grown anaerobically at $30^{\circ} \mathrm{C}$ to an $E_{660}$ of $0.30 . \mathrm{NaCl}$ was added to this logarithmically growing culture to a final concentration of $0.3 \mathrm{M}$, incubation was continued at $30^{\circ} \mathrm{C}$, and readings of $E_{660}$ were made at 5 min intervals.

Induction of bacterial autolysis. Autolysis was induced as described by Kawata \& Takumi (1970), and Higgins, Pooley \& Shockman (1970). The organisms taken at various times were harvested by centrifugation and washed once with cold distilled water. The washed organisms were suspended in $0.0 \mathrm{r} \mathrm{M}$-phosphate buffer $\left(\mathrm{pH} \mathrm{6.0)}\right.$ ) and allowed to autolyse at $30^{\circ} \mathrm{C}$, $E_{660}$ being measured at 5 min intervals.

Antibiotic treatment. Cultures grown anaerobically at $30{ }^{\circ} \mathrm{C}$ to an $E_{660}$ of 0.25 , were treated for $20 \mathrm{~min}$ at $30{ }^{\circ} \mathrm{C}$ with $(\mu \mathrm{g} / \mathrm{ml})$ : chlortetracycline (TC, Takeda Co.), I00; or chloramphenicol (CM, Sankyo Co.), 250; or mitomycin C (MC, Kyowa Hakko Co.), 4. Excess antibiotic was removed by centrifuging for $5 \mathrm{~min}$ at $9000 \mathrm{~g}$. The harvested organisms were resuspended in prewarmed TYA broth to an $E_{660}$ of 0.25 , and the culture incubated in the usual manner with readings of $E_{660}$ being made at $30 \mathrm{~min}$ intervals. A sample of antibiotictreated culture was withdrawn at a suitable time and exposed to $0.3 \mathrm{M}-\mathrm{NaCl}$, changes in its $E_{660}$ being monitored for 30 to $60 \mathrm{~min}$.

Estimation of the rate of lysis. The rate of lysis was calculated from the equation: rate = $1000 \times\left(E_{0}-E_{t}\right) / t$ where $E_{0}$ is the initial $E_{660}$ of the culture or suspension, and $E_{t}$ is the terminal $E_{660}$ after lysis for $t \mathrm{~min}$.

Preparation of walls and formalin-treated organisms. Walls of strain NI-4 were prepared as described by Kawata \& Takumi (I97I).

Formalin-treated organisms were prepared by exposing harvested logarithmic phase organisms for $30 \mathrm{~min}$ at room temperature, to $0.067 \mathrm{M}$-phosphate buffer $(\mathrm{pH} \mathrm{6.0)} \mathrm{containing}$ $5 \%(\mathrm{v} / \mathrm{v})$ formalin. The organisms were washed twice with cold phosphate buffer (without formalin), and suspended in similar buffer of $\mathrm{pH} 5 \cdot 5$.

Assay of lytic activity in the lysate induced by $\mathrm{Na}^{+}$-treatment. Lytic activity was assayed 


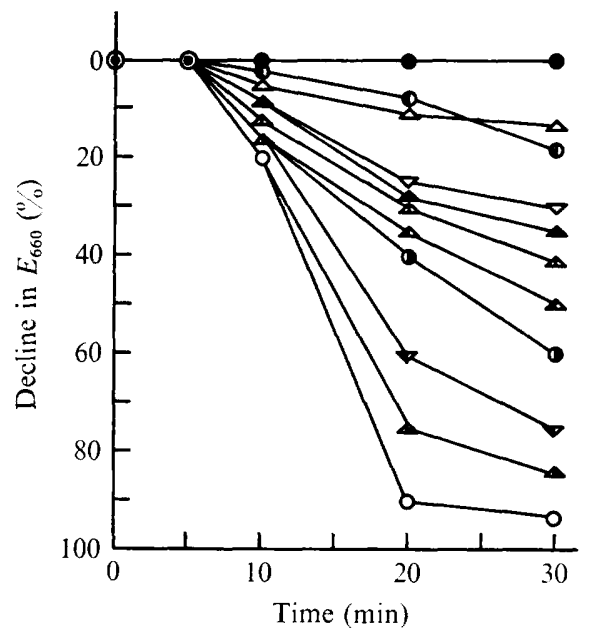

Fig. I

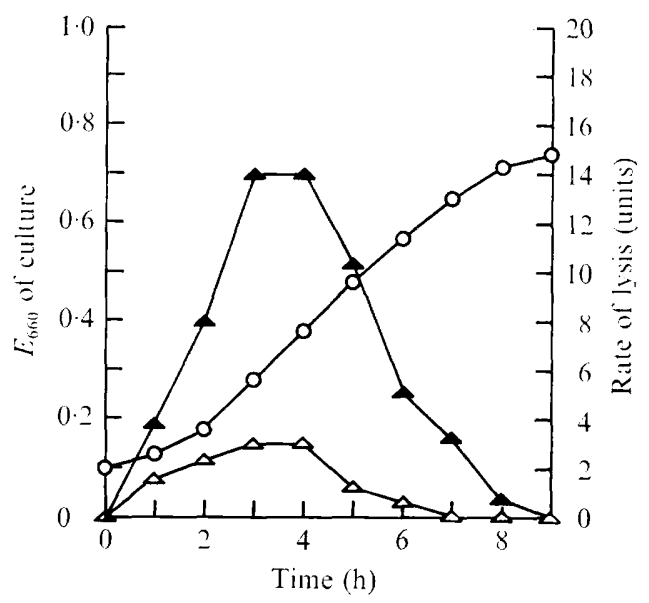

Fig. 2

Fig. I. Inhibition of sodium ion-induced lysis of clostridia by various chemical compounds. $O$, No inhibitor; glutaraldehyde $(0.1 \%, \mathrm{v} / \mathrm{v}), \mathrm{OsO}_{4}(0.1 \%, \mathrm{w} / \mathrm{v}), \mathrm{CuSO}_{4}\left(\mathrm{IO}^{-3} \mathrm{M}\right) ; \mathrm{O}, \mathrm{CuSO}_{4}\left(5 \times 10^{-4}\right.$ $\mathrm{M}) ; 0, \mathrm{CuSO}_{4}\left(\mathrm{IO}^{-4} \mathrm{M}\right) ; \triangle$, formalin $(0.5 \%, \mathrm{v} / \mathrm{v}) ; \triangle$, formalin $(0 . \mathrm{I} \%, \mathrm{v} / \mathrm{v}) ; \nabla, \mathrm{PCMB}\left(\mathrm{IO}^{-3} \mathrm{M}\right)$; $\boldsymbol{\nabla}$, PCMB $\left(5 \times 10^{-4} \mathrm{M}\right) ; \boldsymbol{\Delta}$, fradiomycin $(500 \mu \mathrm{g} / \mathrm{ml})$, polymyxin B $(500 \mu \mathrm{g} / \mathrm{ml}) ; \boldsymbol{\Delta}$, FR $(100 \mu \mathrm{g} / \mathrm{ml})$ and $\mathrm{PB}(100 \mu \mathrm{g} / \mathrm{ml}) ; \Delta$, uranium nitrate $\left(10^{-3} \mathrm{M}\right)$. Initial $E_{660}$ of each culture was 0.30 .

Fig. 2. Lysis rates of sodium ion-induced lysis and autolysis of various aged clostridia. $O$, Growth curve; $\Delta$, lysis rate of $\mathrm{Na}^{+}$-induced lysis; $\Delta$, lysis rate of autolysis.

by the decrease in turbidity of suspensions of walls or of formalin-treated organisms. $\mathrm{Na}^{+}-$ inducedlysate $(2.5 \mathrm{ml})$ and $2.5 \mathrm{ml}$ substrate were suspended in $0.067 \mathrm{M}$-phosphate buffer $(\mathrm{pH} 5.5)$ to a initial $E_{660}$ of $0.30 ; \mathrm{pH} 5.5$ phosphate buffer was used, since the $\mathrm{pH}$ of the lysate was $5 \cdot 5$. A control tube contained lysate boiled for $5 \mathrm{~min}$.

Assay of bacteriocin-associated endolysin. Samples were withdrawn at $30 \mathrm{~min}$ intervals from a mitomycin C-treated culture. A portion of each sample was immediately centrifuged at $9000 \mathrm{~g}$ for Io $\mathrm{min}$, and the supernatant was assayed for extracellular endolysin activity. Another portion was exposed to $0.3 \mathrm{M}-\mathrm{NaCl}$ at $30^{\circ} \mathrm{C}$ until lysis was completed, when the lysate was centrifuged at $60000 \mathrm{~g}$ for $60 \mathrm{~min}$ to remove bacteriocin, and the supernatant was assayed for total (extracellular and intracellular) endolysin activity. To distinguish between endolysin and autolysin, formalin-treated bacteria were used as the substrate in this experiment since endolysin but not autolysin acted on this substrate.

\section{RESULTS •}

\section{Inhibition of sodium ion-induced lysis}

Effect of chemical agents. In preliminary work, it was found that $\mathrm{Na}^{+}$-induced lysis was inhibited by small concentrations $\left(\mathrm{IO}^{-3}\right.$ to $\mathrm{IO}^{-4} \mathrm{M}$ ) of heavy metal cations such as $\mathrm{Cu}^{2+}$, $\mathrm{Ag}^{2+}$ and $\mathrm{Pb}^{2+}$. Other known inhibitors of lysis (Ralston, Lieberman, Baer \& Krueger, 1957; Ralston, Baer, Lieberman \& Krueger 1961; Doughty \& Mann, 1967; Goepfert \& Naylor, 1967; Higgins et al. 1970) were therefore tested as follows. The compounds were added to the growing cultures between o and $5 \mathrm{~min}$ before treatment with $\mathrm{NaCl}$. After addition of $\mathrm{NaCl}$, the $E_{660}$ was followed for a further $30 \mathrm{~min}$ at $30^{\circ} \mathrm{C}$ (Fig. I). Fixatives such as glutaraldehyde, formalin, osmium tetroxide $\left(\mathrm{OsO}_{4}\right)$, and uranium nitrate were potent inhibitors of the $\mathrm{Na}^{+}$-induced lysis. These fixatives protect the bacteria from auto- 


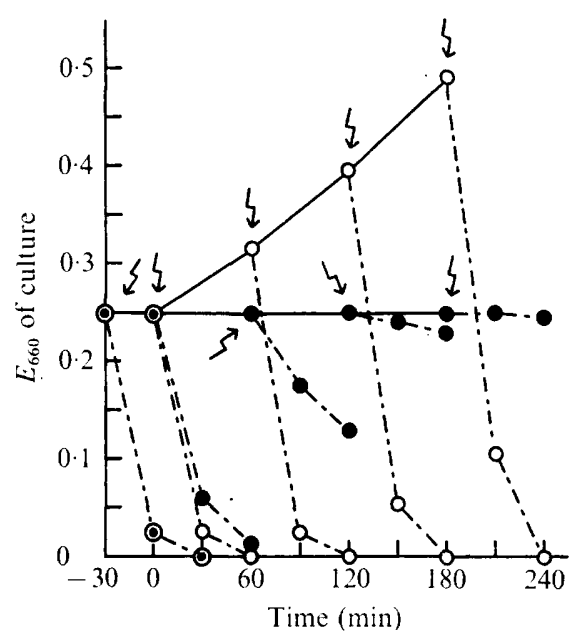

Fig. 3

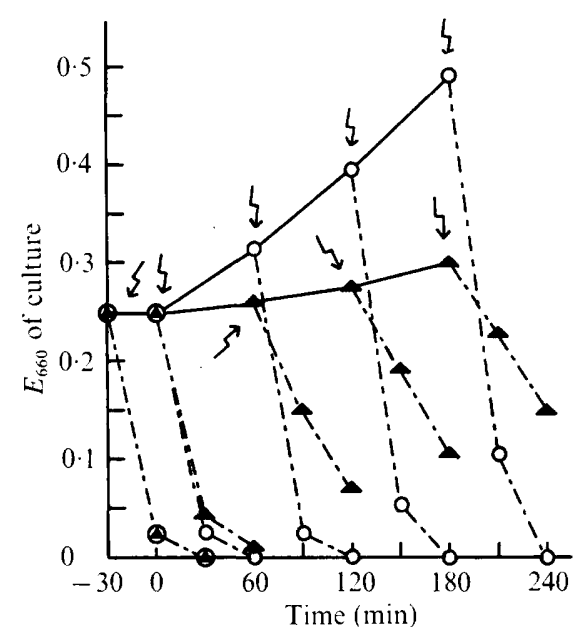

Fig. 4

Fig. 3. Resistance to sodium ion-induced lysis of tetracycline-treated clostridia. $\mathrm{O}-\mathrm{O}$, Growth curve of normal organisms; $\longrightarrow$, growth curve of TC-treated organisms; $0-.-0$, lysis curve of normal organisms; --.-, lysis curve of TC-treated organisms. TC: $100 \mu \mathrm{g} / \mathrm{ml}$. Excess TC was removed by centrifugation. $\mathrm{NaCl}(0.3 \mathrm{M})$ was added at the various times indicated by the arrows, and incubation was continued for $60 \mathrm{~min}$ at $30^{\circ} \mathrm{C}$.

Fig. 4. Resistance to sodium ion-induced lysis of chloramphenicol-treated clostridia. $O-O$, growth curve of normal organisms; $\boldsymbol{\Delta}-\boldsymbol{\Delta}$, growth curve of $\mathrm{CM}$-treated organisms; $\mathrm{O}-\cdot-\mathrm{O}$, lysis curve of normal organisms; $\Delta-\cdot-\mathbf{A}$, lysis curve of CM-treated organisms. CM; $250 \mu \mathrm{g} / \mathrm{ml}$. The other conditions were the same as for Fig. 3.

lysis (Higgins et al. 1970). Sodium ion-induced lysis was also inhibited by $p$-chloromercuribenzoate (PCMB), fradiomycin (FR, neomycin, Takeda Co.) and polymyxin B (PB, Pfizer Taito Co.).

These results indicate that some enzymic reaction participates in $\mathrm{Na}^{+}$-induced lysis, and that free sulphydryl groups are involved.

Effect of $p H$. The culture was adjusted to the desired $\mathrm{pH}$ with I $\mathrm{N}-\mathrm{NaOH}$ (or I $\mathrm{N}-\mathrm{NH}_{4} \mathrm{OH}$ ) and I N-HCl before treatment with $\mathrm{NaCl}$. After the addition of $\mathrm{NaCl}$, the $E_{660}$ was followed for $30 \mathrm{~min}$ at $30^{\circ} \mathrm{C}$. Lysis was clearly observed at $\mathrm{pH} 5.0$ to 7.0 , being most rapid at $\mathrm{pH} 5.7$ to $6 \cdot 0$.

Effect of temperature. The culture was prewarmed or precooled to temperatures between $\circ$ and $50^{\circ} \mathrm{C}$ before treatment with $\mathrm{NaCl}$. After the addition of $\mathrm{NaCl}$, the $E_{660}$ was followed for $30 \mathrm{~min}$ at each temperature. The rate of lysis increased with temperature to a maximum at $35^{\circ} \mathrm{C}$. No lysis took place below $5{ }^{\circ} \mathrm{C}$ or above $40^{\circ} \mathrm{C}$.

\section{Effect of growth phase on sodium ion-induced lysis and autolysis}

Portions of a culture were withdrawn at intervals to measure the organisms' sensitivity to $\mathrm{Na}^{+}$-induced lysis and their tendency to autolyse (Fig. 2). Actively growing organisms from young cultures were highly sensitive to $\mathrm{Na}^{+}$-induced lysis and autolysis. Both sensitivities decreased in organisms taken from older cultures. The rate of $\mathrm{Na}^{+}$-induced lysis was minimal at the stationary phase of growth, and that of autolysis was minimal at the late logarithmic phase.

These results suggest that active growth and a propensity for autolysis could be essential for $\mathrm{Na}^{+}$-induced lysis. 


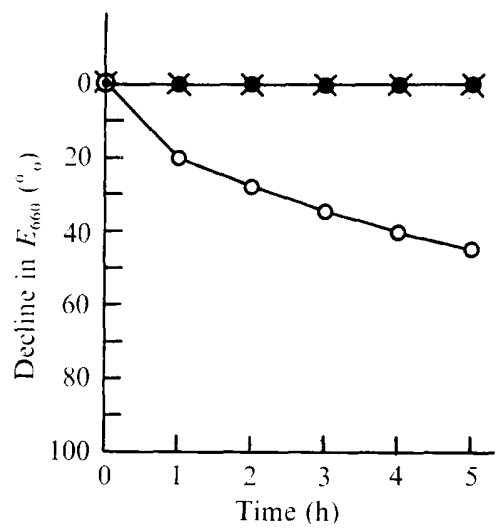

Fig. 5. Wall lytic activity in the lysate induced by sodium ion treatment. $\bigcirc$, Walls + lysate; 9 , walls +heated lysate; $x$ formalin-treated organisms +lysate. Incubation was at $30{ }^{\circ} \mathrm{C}$. Initial $E_{660}$ of each suspension was 0.30 .

Resistance to sodium ion-induced lysis of tetracycline- and chloramphenicol-treated organisms

Treatment with antibiotics such as chloramphenicol (CM) results in rapid decrease in the rate of autolysis (Shockman, 1965; Higgins et al. 1970; Pooley \& Shockman, 1970; Stewart \& Marmur, 1970). Organisms were therefore treated with chlortetracycline (TC) or $\mathrm{CM}$ and both treatments resulted in inhibition of growth and a decrease in the rate of $\mathrm{Na}^{+}$ induced lysis (Figs. 3 and 4). It was also evident that TC and CM were not chemical inhibitors such as FR and PB; TC had a more pronounced effect on both $\mathrm{Na}^{+}$-induced lysis and growth than had CM. The TC-treated organisms completely stopped growing about $60 \mathrm{~min}$ after exposure to the antibiotic, and developed their insensitivity to $\mathrm{Na}^{+}-$ induced lysis after some $\mathrm{I} 20 \mathrm{~min}$. With $\mathrm{CM}$-treated organisms, slow $\mathrm{Na}^{+}$-induced lysis was demonstrable at all times.

Thus, $\mathrm{Na}^{+}$-induced lysis was inhibited by antibiotics known to impair autolysis.

\section{Wall lytic activity in the lysate obtained by sodium ion treatment}

As shown in Fig. 5, $\mathrm{Na}^{+}$-induced lysate had some lytic activity on isolated walls, but not on formalin-treated organisms. To determine whether or not this lytic activity was enzymic in origin, the $\mathrm{Na}^{+}$-induced lysate was boiled for $5 \mathrm{~min}$. The heat-treated preparation did not digest isolated walls (Fig. 5).

This suggests the presence of a lytic enzyme (possibly autolysin) in $\mathrm{Na}^{+}$-induced lysate.

\section{Sodium ion-induced lysis of organisms treated with mitomycin $C$}

Another aspect of $\mathrm{Na}^{+}$-induced lysis was examined using mitomycin $\mathrm{C}$ (MC)-treated organisms in which the production of phage tail-like bacteriocin was induced (clostocin $\mathrm{O}$; Ogata et al. 1972).

When a logarithmically growing culture $\left(E_{660}=0.25\right)$ was exposed to $4 \mu \mathrm{g} \mathrm{MC} / \mathrm{m}$, the $E_{660}$ of the culture increased as shown in Fig. 7. Normal lysis (MC-induced lysis) began I 80 min after pre-cultivation (Fig. 7), and finished some $5 \mathrm{~h}$ or more later (Ogata et al. 1972). By treatment with $\mathrm{NaCl}, \mathrm{Na}^{+}$-induced lysis was provoked at various times. The lysis curve and lysis rate displayed by organisms harvested at different incubation times are shown in Figs. 6 and 7, respectively. MC was evidently not acting as a chemical inhibitor. 


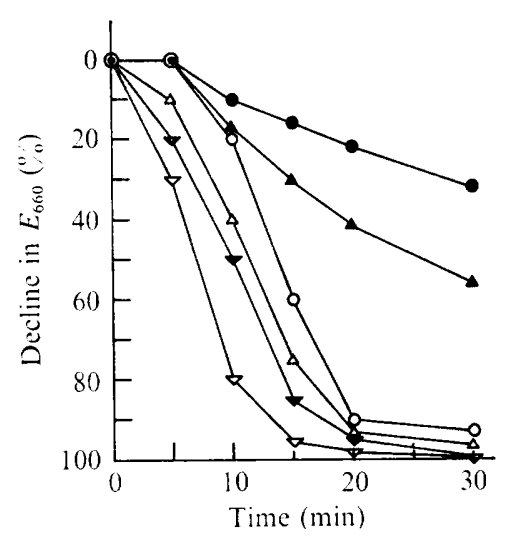

Fig. 6

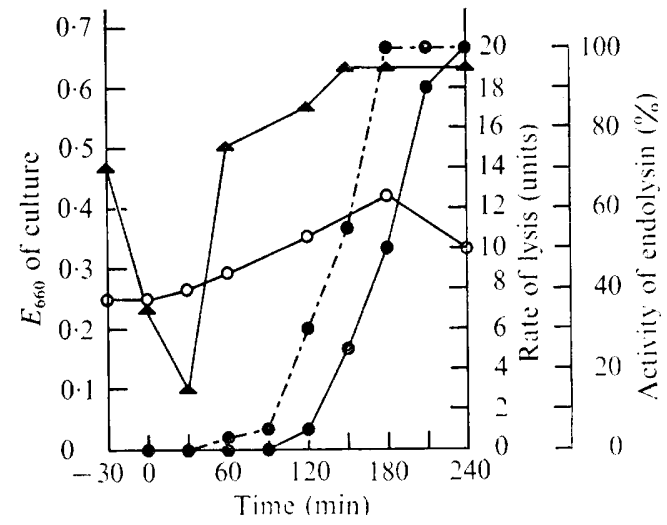

Fig. 7

Fig. 6. Sodium ion-induced lysis of mitomycin $\mathrm{C}$-treated clostridia. $\mathrm{O}$, No MC. The following indicate $0.3 \mathrm{M}-\mathrm{NaCl}$-added times (see $\mathrm{O}-\mathrm{O}$ line in Fig. 7) with $4 \mu \mathrm{g} \mathrm{MC} / \mathrm{ml}: \boldsymbol{\Delta}, 0 \mathrm{~min}$; $\boldsymbol{0}$, $30 \mathrm{~min} ; \triangle, 60 \mathrm{~min} ; \nabla, 120 \mathrm{~min} ; \nabla, 180 \mathrm{~min}$. The initial $E_{660}$ was not identical for each culture $\left(E_{660}\right.$ : 0.25 to 0.42 , see $\mathrm{O}-\mathrm{O}$ line in Fig. 7). The experiment was performed as described in Fig. 3 .

Fig. 7. Lysis rate of sodium ion-induced lysis of mitomycin $\mathrm{C}$-treated clostridia and production of clostocin $\mathrm{O}$-endolysin at various times after mitomycin $\mathrm{C}$ treatment. $\mathrm{O}-\mathrm{O}$, Growth curve of MC-treated organisms; $\boldsymbol{\Delta - \Lambda}$, lysis rate of $\mathrm{Na}^{+}$-induced lysis; $-\mathbf{O}$, extracellular activity of endolysin; - - - extracellular and intracellular activity of endolysin. Maximum activity of endolysin was $\mathrm{I} 2$ units.

During pre-cultivation, $\mathrm{MC}$-treated organisms became relatively resistant to $\mathrm{Na}^{+}$-induced lysis, maximum resistance being displayed some $30 \mathrm{~min}$ after pre-cultivation. However, the organisms returned to their state of high sensitivity after about $60 \mathrm{~min}$. Their rate of lysis was greater than that of normal organisms, and the $5 \mathrm{~min}$ lag period usually observed in the case of normal organisms was absent. The lysis rate increased still further as time proceeded, reaching its maximum at 150 to $180 \mathrm{~min}$, which was also the time at which MC-induced lysis was initiated. A possible explanation of this enhanced sensitivity to lysis is offered below.

\section{Production of bacteriocin-associated endolysin during the development of mitomycin $\mathrm{C}$-treated organisms}

Production of phage or of phage tail-like bacteriocin, and the release of these particles, are accompanied by the lysis of the producer organisms (Ralston et al. 1957; 1961; Koch \& Dreyer, I958; Kageyama, Ikeda \& Egami, I964; Doughty \& Mann, I967; Goepfert \& Naylor, 1967; Bradley, 1969). Such lysis is caused by the breakdown of wall by phage- or bacteriocin-associated endolysin.

Fig. 7 shows extracellular and intracellular development of bacteriocin-associated endolysin (clostocin O-endolysin). No extracellular activity of this endolysin could be detected until $90 \mathrm{~min}$ after pre-cultivation, and little active endolysin was present in the organisms at $60 \mathrm{~min}$. The content of endolysin increased with the age of the culture, a portion being released from the bacteria. Maximum activity was observed at the time of $\mathrm{MC}$-induced lysis, and the rate of $\mathrm{Na}^{+}$-induced lysis accelerated according to the increased content of active endolysin.

These results indicate that the high sensitivity of $\mathrm{MC}$-induced organisms to $\mathrm{Na}^{+}$-induced lysis is likely to be due to the biosynthesis of endolysin. 


\section{DISCUSSION}

Sodium ion-induced lysis is a specific phenomenon manifested by Clostridium species (Ogata \& Hongo, I973). It seemed to be due to ion antagonism between $\mathrm{Na}^{+}$added and bivalent cations in the medium and on the bacterial surface, or to some physical action of $\mathrm{Na}^{+}$. However, there were indications that the lysis was enzymically caused, e.g. it was inhibited by chemicals known to be inhibitors of enzymes and of autolysis. The cultural conditions which favoured lysis were those in which there was marked synthesis of autolysin. Furthermore, the lysate produced by $\mathrm{Na}^{+}$-treatment had lytic activity against isolated walls. Since no lytic enzymes other than autolysin are known to exist in normal growing organisms, our findings suggest that the lysis induced by $\mathrm{Na}^{+}$-treatment is catalysed by autolysin. Autolysin may play some part in the normal growth of bacteria (Shockman, Thompson \& Conover, 1967; Anderson, Matsuhashi, Haskin \& Strominger, 1965; Shockman, 1965; Young, I966; Strominger, Izaki, Matsuhashi \& Tipper, 1967); action of autolysin on peptidoglycan can cause local weakening of the rigid wall and so facilitate insertion of newly synthesized wall material.

Treatment of rapidly growing organisms with antibiotics, including CM, MC, actinomycin D and cellocidin, results in thickening of their walls (Shockman, 1965; Higgins et al. I970), rapid loss of their ability to autolyse, and a gradual decrease in their content of the active form of autolysin (Shockman, I965; Higgins et al. 1970; Pooley \& Shockman, 1970; Stewart \& Marmur, 1970). At present, we have no precise knowledge of the condition of antibiotic-treated organisms, but it is clear that TC- or CM-treatment results in a rapid decrease in the rate of $\mathrm{Na}^{+}$-induced lysis. Antibiotic-treated organisms developed their insensitivity to $\mathrm{Na}^{+}$-induced lysis when growth completely stopped. The continuing sensitivity of CM-treated organisms could be due to the continuing synthesis of autolysin and wall, since $\mathrm{CM}$ still permitted growth. These results indicate that $\mathrm{Na}^{+}$-induced lysis is inhibited by those antibiotics known to inhibit autolysis. It may also be said that the resistance to $\mathrm{Na}^{+}$-induced lysis of antibiotic-treated organisms would depend on the decrease in their content of autolysin and the increase in thickness of their walls.

Temporary resistance to $\mathrm{Na}^{+}$-induced lysis of $\mathrm{MC}$-treated organisms could be explained on the same basis as the resistance of TC- or CM-treated organisms. The very high sensitivity of MC-treated organisms would be due to the production of clostocin O-endolysin. This lysin was clearly different from the lysin of normal organisms (autolysin) in its substrate specificity, for it was active against formalin- and chloroform-treated organisms (Sekiguch \& Cohen, 1964; Salser, Gesteland \& Bolle, 1967) as well as on isolated walls, whilst autolysin was only active on isolated walls. There was much more endolysin than autolysin in the lysate (S. Ogata, Y. Tahara, A. Umeda, S. Yoshino \& M. Hongo, unpublished). The endolysin when present in small concentrations in MC-treated organisms at early times may cause expansion of the wall, but when present in greater concentrations, as at later times, it may cause breakdown of the wall. FR and PB were specific inhibitors of both lysins (Ogata et al. unpublished), whose enzymic properties will be reported in greater detail in a future paper.

From these observations, it may be concluded that the rapid lysis of strain NI-4 by the addition of $\mathrm{Na}^{+}$is due to the action of wall lytic enzymes such as autolysin and bacteriocinassociated endolysin. However, the role of $\mathrm{Na}^{+}$remains obscure and is being further investigated in our laboratory. 
The authors thank S. Yoshino, Y. Ikeda, K. H. Choi and Y. Tahara for their technical assistance in some of this work, which was partly supported by a Grant-in-aid for Scientific Research from the Ministry of Education of Japan.

\section{REFERENCES}

Anderson, J. S., Matsuhashi, M., Haskin, H. A. \& Strominger, J. L. (1965). Lipid-phosphoacetylmuramyl-pentapeptide and lipid-phosphodisaccharide-pentapeptide: presumed membrane transport intermediates in cell wall synthesis. Proceedings of the National Academy of Sciences of the United States of America 53, 881-889.

BRADLEY, D. E. (1969). Ultrastructure of bacteriophages and bacteriocins. Bacteriological Reviews 3r, 230-314.

Doughty, C. C. \& ManN, J. A. (1967). Purification and properties of a bacteriophage-induced cell wall peptidase from Staphylococcus aureus. Journal of Bacteriology 93, 1089-1095.

GoepferT, J. M. \& NAYLOR, H. B. (1967). Characteristics of a lytic enzyme induced by bacteriophage infection of Micrococcus lysodeikticus. Journal of Virology I, 70I-710.

Higgins, M. L., Pooley, H. M. \& Shockman, G. D. (1970). Site of initiation of cellular autolysis in Streptococcus faecalis as seen by electron microscopy. Journal of Bacteriology 103, 504-514.

Hongo, M. \& Murata, A. (1965). Bacteriophages of Clostridium saccharoperbutylacetonicum. I. Some characteristics of the twelve phages obtained from the abnormally fermented broths. Agricultural and Biological Chemistry, Tokyo 29, II 35-II39.

IIZIMA, T. \& IKEDA, Y. (1969). The saline-sensitive phenomenon in Bacillus subtilis. Journal of General and Applied Microbiology 15, 453-46I.

Kageyama, M., IKeda, K. \& Egami, F. (1964). Studies of a pyocin: biological properties of the pyocin. Journal of Biochemistry 55, 59-64.

KAWATA, T. \& TAKUMI, K. (I970). Initiation site of autolysis in Clostridium perfringens type A as revealed by electron microscopy. Journal of General and Applied Microbiology 16, 34I-345.

KAWATA, T. \& TAKUMI, K. (1971). Autolytic enzyme system of Clostridium botulinum: partial purification and characterization of an autolysin of Clostridium botulinum type A. Japanese Journal of Microbiology r5, I-IO.

Koch, G. \& Dreyer, W. J. (1958). Characterization of an enzyme of phage T2 as a lysozyme. Virology 6 , 291-293.

Ogata, S., Mihara, O., IKeda, Y. \& Hongo, M. (1972). Bacteriocins of non-pathogenic Clostridium species: inducible phage tail-like particles of Clostridium saccharoperbutylacetonicum and its related strains. Agricultural and Biological Chemistry, Tokyo 36, 1413-1421.

Ogata, S. \& Hongo, M. (1973). Bacterial lysis of Clostridium species: lysis of Clostridium species by univalent cation. Journal of General and Applied Microbiology 19, 25I-264.

Pooley, H. M. \& Shockman, G. D. (1970). Relationship between the location of autolysin, cell wall synthesis, and the development of resistance to cellular autolysis in Streptococcus faecalis after inhibition of protein synthesis. Journal of Bacteriology 103, 457-466.

Ralston, D. J., Lieberman, M., Baer, B. \& Krueger, A. P. (1957). Staphylococcal virolysin, a phageinduced lysin: its differentiation from autolysin of normal cells. Journal of General Physiology 40, $79 \mathrm{I}-807$.

Ralston, D. J., Baer, B., Lieberman, M. \& Krueger, A. P. (I96I). Virolysin, a virus-induced lysin: its appearance and function in phage-infected Staphylococci. Journal of General Microbiology 24, 313-325.

Salser, W., Gesteland, R. F. \& Bolle, A. (1967). In vitro synthesis of bacteriophage lysozyme. Nature, London 215, 588-59I.

Sato, T., SuzukI, Y., IZAKI, K. \& TAKaHashi, H. (1971). Some features of saline-sensitive phenomenon in Escherichia coli: protection and recovery by magnesium ion. Journal of General and Applied Microbiology $17,37 \mathrm{I}-382$.

Sato, T., IZAKI, K. \& TAKahashi, H. (1972). Recovery of cells of Escherichia coli from injury induced by sodium chloride. Journal of General and Applied Microbiology 18, 307-317.

SeKiguchi, M. \& Cohen, S. S. (1964). The synthesis of messenger RNA without protein synthesis. II. Synthesis of phage-induced RNA and sequential enzyme production. Journal of Molecular Biology 8, 638-659.

Shockman, G. D. (1965). Symposium on the fine structure and replication of bacteria and their part. IV. Unbalanced cell-wall synthesis: autolysis and cell-wall thickening. Bacteriological Reviews 29, 345-358. 
Shockman, G. D., Thompson, J. S. \& Conover, M. J. (1967). Autolytic enzyme system of Streptococcus faecalis. II. Partial characterization of the autolysin and its substrate. Biochemistry 6, 1054-1065.

Stewart, C. R. \& MARmUR, J. (1970). Increase in lytic activity in competent cells of Bacillus subtilis after uptake of deoxyribonucleic acid. Journal of Bacteriology ror, 449-455.

Strominger, J. L., Izaki, K., Matsuhashi, M. \& Tipper, D. J. (1967). Peptidoglycan transpeptidase and D-alanine carboxypeptidase: penicillin-sensitive enzymatic reactions. Federation Proceedings 26, 9-22.

Young, F. E. \& SpIZIZEN, J. (1963). Biochemical aspects of competence in the Bacillus subtilis transformation system. II. Autolytic enzyme activity of cell walls. Journal of Biological Chemistry 238, 31 26-31 30.

Young, F. E. (I966). Autolytic enzyme associated with cell walls of Bacillus subtilis. Journal of Biological Chemistry 24I, 3462-3467. 